\title{
Circulation of Sexually Transmitted Diseases Bacteria among Pregnant Women in the $21^{\text {st }}$ Century
}

\author{
Ali Badamchi* \\ Children's Medical Center Hospital, Tehran University of Medical Sciences, Iran
}

Received: January 16, 2018; Published: January 23, 2018

*Corresponding author: Ali Badamchi, Children's Medical Center Hospital, Tehran University of Medical Sciences, Tehran, Iran, Fax: 02133075364;

Email: badamchiy12@gmail.com

Keywords: Chlamydia trachomatis; Sexually transmitted disease

\section{Introduction}

Chlamydia trachomatis and neisseria gonorrhoeae are the most common bacterial causes of lower genital tract infection nowadays. According to the WHO, 101.5 million chlamydial infections are reported annually worldwide [1]. The prevalence of infection caused by C. trachomatis in pregnant women ranges from $2-35 \%$ [2]. Reports from Iran, the variable rates of chlamydial infections are showed among women (2.75-22\%) [3-5]. Therefore, the C. trachomatis infection screening is one of the most important hygiene measures during pregnancy. The variable prevalence of $\mathrm{C}$. trachomatis and $\mathrm{N}$. gonorrhoeae was found in Brazilian pregnant women, as $9.8 \%$ to $11.1 \%$ for C. trachomatis and $0 \%$ to $1.5 \%$ for N. Gonorrhoeae [6]. According to recent reports from USA, the high prevalence of C. trachomatis (0-77\%) and N. gonorrhoeae $(0-35 \%)$ were reports in pregnant individuals [7]. Several studies on European pregnant women for detection of C. trachomatis have revealed the prevalence rate of infection varies from 0 to $37 \%$ [8]. Despite the high level of health in the European and American countries, the role of sexually transmitted diseases among pregnant women in European countries is much higher than Islamic countries, and as a result, they will have more drug resistance than Islamic countries. It seems, despite most diseases found in religious groups, Sexual diseases in Islamic countries due to commitment and Loyalty to his wife is less visible.

\section{Conclusion}

According to potentially dangerous complications of chlamydial and gonococcal infections, the results endorse that pregnant women should be screened routinely for the presence of Chlamydia and gonococcus bacteria.

\section{References}

1. Malhotra M, Sood S, Mukherjee A, Muralidhar S, Bala M (2013) Genital Chlamydia trachomatis: An update. Indian J Med Res 138(3): 303-316.

2. Da Ros CT, Schmitt Cda S (2008) Global epidemiology of sexually transmitted diseases. Asian J Androl 10(1): 110-114.

3. Ghanaat J, Afshari JT, Ghazvini K, Malvandi M (2008) Prevalence of genital Chlamydia in Iranian males with urethritis attending clinics in Mashhad. East Mediterr Health J 14(6): 1333-1337.

4. Badami N SMRoCt (2001) Mycoplasma hominis and Ureaplasma urealyticum in infertile females and control group. Iranian Journal of Public Health 30: 57-60.

5. Hasanabad MH MM, Bahador A, Fazel N, Rakhshani H, Majnooni A (2011) Prevalence of Chlamydia trachomatis and Mycoplasma genitalium in pregnant women of Sabzevar-Iran. Iranian journal of microbiology 3(3): 123-128.

6. Travassos AGÁ BC, Netto EM, De Almeida Fernandes S, Rutherford GW, Queiroz CM (2012) Prevalence of sexually transmitted infections among HIV-infected women in Brazil. The Brazilian Journal of Infectious Diseases 16(6): 581-585.

7. Chan, Philip A, Ashley Robinette, Madeline Montgomery, Alexi Almonte, et al. (2016) Extragenital infections caused by chlamydia trachomatis and Neisseria gonorrhoeae: a review of the literature. Infectious diseases in obstetrics and gynecology.

8. Lanjouw E, Ouburg S, De Vries HJ, Stary A, Radcliffe K (2016) 2015 European guideline on the management of Chlamydia trachomatis infections. International journal of STD \& AIDS 27(5): 333-348. 
(C) (i) This work is licensed under Creative

Submission Link: http://biomedres.us/submit-manuscript.php

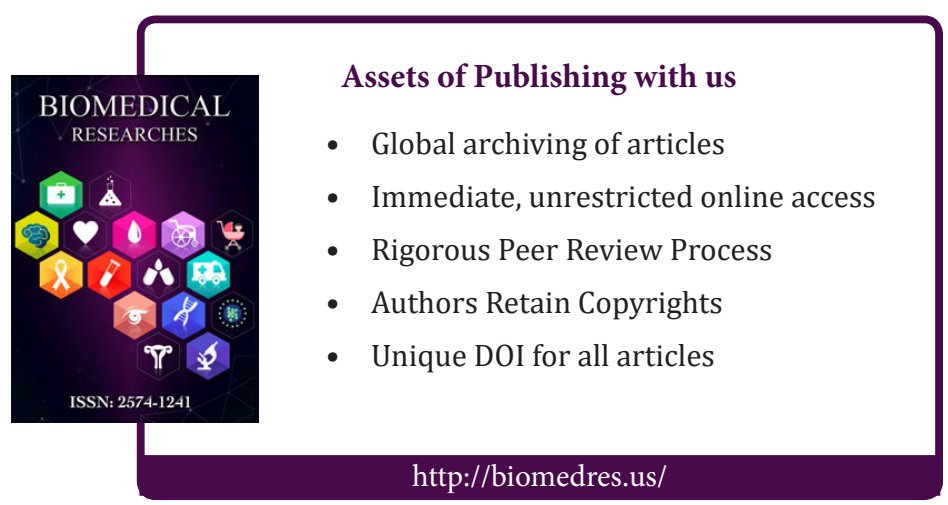

